\title{
Overexpression of S100A4 in human cancer cell lines resistant to methotrexate
}

\author{
Nuria Mencía ${ }^{\dagger 1}$, Elisabet Selga ${ }^{\dagger 1}$, Isabel Rico¹, M Cristina de Almagro', Xenia Villalobos¹, Sara Ramirez' , Jaume Adan², \\ Jose L Hernández² , Véronique Noé1 and Carlos J Ciudad*1
}

\begin{abstract}
Background: Methotrexate is a chemotherapeutic drug that is used in therapy of a wide variety of cancers. The efficiency of treatment with this drug is compromised by the appearance of resistance. Combination treatments of MTX with other drugs that could modulate the expression of genes involved in MTX resistance would be an adequate strategy to prevent the development of this resistance.

Methods: The differential expression pattern between sensitive and MTX-resistant cells was determined by whole human genome microarrays and analyzed with the GeneSpring GX software package. A global comparison of all the studied cell lines was performed in order to find out differentially expressed genes in the majority of the MTX-resistant cells. S100A4 mRNA and protein levels were determined by RT-Real-Time PCR and Western blot, respectively. Functional validations of S100A4 were performed either by transfection of an expression vector for S100A4 or a siRNA against S100A4. Transfection of an expression vector encoding for $\beta$-catenin was used to inquire for the possible transcriptional regulation of S100A4 through the Wnt pathway.

Results: S100A4 is overexpressed in five out of the seven MTX-resistant cell lines studied. Ectopic overexpression of this gene in HT29 sensitive cells augmented both the intracellular and extracellular S100A4 protein levels and caused desensitization toward MTX. siRNA against S100A4 decreased the levels of this protein and caused a chemosensitization in combined treatments with MTX. $\beta$-catenin overexpression experiments support a possible involvement of the Wnt signaling pathway in S100A4 transcriptional regulation in HT29 cells.

Conclusions: S100A4 is overexpressed in many MTX-resistant cells. S100A4 overexpression decreases the sensitivity of HT29 colon cancer human cells to MTX, whereas its knockdown causes chemosensitization toward MTX. Both approaches highlight a role for S100A4 in MTX resistance.
\end{abstract}

\section{Background}

Methotrexate (MTX) is a classical drug that is used for the treatment of a wide variety of cancers, both alone and in combination with other chemotherapeutic agents $[1,2]$. Drug resistance is usually observed upon treatment with MTX, thus compromising its effectiveness. Combination treatments of MTX with other drugs that could modulate the expression of genes involved in MTX resistance would be an adequate strategy to prevent the development of resistance. With this premise, we searched for genes differentially expressed in common among seven

\footnotetext{
*Correspondence: cciudad@ub.edu

1 Department of Biochemistry and Molecular Biology, School of Pharmacy,

University of Barcelona, Diagonal Avenue 643, Barcelona, Spain

+ Contributed equally

Full list of author information is available at the end of the article
}

MTX-resistant cell lines representative of five different types of cancer. In that work we identified and validated DHFR as the only gene overexpressed in common among all the studied cell lines [3]. We also identified and validated other genes that, aside of DHFR, played an important role in MTX resistance (AKR1C1, DKK1) [4] or that indirectly contributed to the resistance phenotype (MSH3, SSBP2, ZFYVE16) [5].

In the present report, we identified genes differentially expressed in at least 4 out of the seven cell lines. Among the genes that fulfilled this requisite, we found some genes that we had previously studied as modulators of MTX resistance, and S100A4, a gene overexpressed in five out of the seven cell lines studied. 
S100A4 is a member of the S100 calcium binding protein family, which is composed of more than 20 members. Their name was given because they are soluble in $100 \%$ saturated ammonium sulfate [6]. As many of the S100 family members, S100A4 is a symmetric homodimer characterized by the presence of two calcium binding sites of the EF-hand type (helix-loop-helix) [7] that enable S100 proteins to respond to calcium stimulus induced by cell signaling.

S100A4 has been described to be involved in a wide variety of intra- and extracellular processes, such as protein phosphorylation, dynamics of cytoskeleton components or $\mathrm{Ca}^{2+}$ homeostasis, which are regulated through interaction of S100A4 with its target proteins [8,9]. Overexpression of S100A4 has been associated with tumor malignancy [10] as well as to metastasis [11], angiogenesis [12] and chemoresitance [13].

In this work, we searched for genes differentially expressed in common among cell lines resistant to MTX. We identified S100A4 as a gene overexpressed in five out of the seven MTX-resistant cell lines studied, which had been previously associated with chemotherapy resistance. Functional validations using either an expression vector encoding for S100A4 or siRNA against its RNA show a role for S100A4 in MTX resistance.

\section{Methods}

\section{Cell Lines}

Cell lines representative of five types of human cancer were used: HT29 and Caco-2 of colon cancer, MCF-7 and MDA-MB-468 of breast cancer, MIA PaCa-2 of pancreatic cancer, $\mathrm{K} 562$ of erythroblastic leukemia, and Saos-2 of osteosarcoma [3]. Resistant cells were obtained in the laboratory upon incubation with stepwise concentrations of MTX (Lederle) as previously described [4]. HT29, Caco-2 and K562 resistant cells were able to grow in 10${ }^{5} \mathrm{M}$ MTX, which corresponds to a 1000 -fold increase in resistance with respect to their respective sensitive cells; MIA PaCa-2, Saos-2, MCF-7 and MDA-MB-468 were resistant to $10^{-6} \mathrm{M} \mathrm{MTX}$, which represents an increase in resistance of 100 times with respect to their sensitive counterparts.

\section{Cell Culture}

Human cell lines were routinely grown in Ham's F12 medium supplemented with $7 \%$ fetal bovine serum (FBS, both from Gibco) at $37^{\circ} \mathrm{C}$ in a $5 \% \mathrm{CO}_{2}$ humidified atmosphere. Resistant cells were routinely grown in selective DHFR medium (-GHT medium, GIBCO) lacking glycine, hypoxanthine and thymidine, the final products of DHFR activity. This medium was supplemented with $7 \%$ dialyzed fetal bovine serum (GIBCO).

\section{Global microarray data analyses of cell lines resistant to MTX}

A global comparison of all cell lines was performed using GeneSpring GX v 7.3.1 (Agilent Technologies), using the latest gene annotations available (March 2009), in order to find differentially expressed genes in the majority of the resistant cell lines. The triplicate samples for each condition, sensitive and resistant, in each of the seven cell lines (42 samples in total) were imported into one single experiment. Normalization was applied in two steps: i) "per Chip normalization" by which each measurement was divided by the 50th percentile of all measurements in its array; and ii) "per Gene normalization" by which the samples of each cell line were normalized against the median of the respective sensitive cells (control). The expression of each gene was calculated as the ratio of the value obtained for each condition relative to the control condition after normalization of the data. Then, data were filtered using the control strength, a control value calculated using the Cross-Gene Error Model on replicates [14] and based on average base/proportional value. Measurements with higher control strength are relatively more precise than measurements with lower control strength. Genes that did not reach this value were discarded. Additional filtering was performed to determine the differentially expressed genes. We selected the genes that displayed a p-value corrected by false discovery rate (Benjamini and Hochberg FDR) of less than 0.05. A list was generated with the genes that passed those filters in at least four out of the seven resistant cell lines.

\section{RT-Real-Time PCR}

mRNA levels were determined by RT-Real-time PCR. Total RNA was extracted from cells using Ultraspec ${ }^{\text {TM }}$ RNA reagent (Biotecx) following the recommendations of the manufacturer. Complementary DNA was synthesized in a total volume of $20 \mu \mathrm{l}$ by mixing $500 \mathrm{ng}$ of total RNA, 125 ng of random hexamers (Roche), in the presence of $75 \mathrm{mM} \mathrm{KCl}, 3 \mathrm{mM} \mathrm{MgCl}, 10 \mathrm{mM}$ dithiothreitol, 20 units of RNasin (Promega), $0.5 \mathrm{mM}$ dNTPs (AppliChem), 200 units of M-MLV reverse transcriptase (Invitrogen) and $50 \mathrm{mM}$ Tris- $\mathrm{HCl}$ buffer, $\mathrm{pH}$ 8.3. The reaction mixture was incubated at $37^{\circ} \mathrm{C}$ for $60 \mathrm{~min}$. The cDNA product was used for subsequent Real-time PCR amplification using an ABI Prism 7000 Sequence Detection System (Applied Biosystems) with $25 \mathrm{ng}$ of the cDNA mixture and the assays-on-demand from Applied Biosystems Hs00243202_m1 for S100A4 and Hs00356991_m1 for APRT.

\section{Gene copy number determination}

Genomic DNA from either sensitive or resistant cells was obtained with the Wizard $^{\mathrm{TM}}$ Genomic DNA Purification Kit (Promega) following the manufacturer's recommen- 
dations. We used $25 \mathrm{ng}$ of DNA and the following primers for Real-Time PCR amplification: For S100A4: 5'CTTCTGG-GCTGCTTAT-3' and 5'-ACTGGGCTTCTGT-TTTCTATC-3'; and for APRT: 5'-CGGGAACCCTCGTCTTTCGCC-3' and 5'-GCCTCGGG-GGCTCAATCTCAC-3'.

\section{Preparation of total extracts for Western blotting}

Total extracts from cells were used to assay S100A4 protein levels. Cells were scrapped in $700 \mu \mathrm{l}$ of ice-cold PBS and centrifuged for $10 \mathrm{~min}$ at 2,000 rpm on a microfuge. The supernatant was discarded and cells were resupended in $50 \mu \mathrm{l}$ of RIPA buffer $(50 \mathrm{mM}$ Tris- $\mathrm{HCl}, 150$ $\mathrm{mM} \mathrm{NaCl}, 5 \mathrm{mM}$ EDTA, 1\% Igepal CA-630 (Sigma), 0.5 $\mathrm{mM}$ PMSF, Protease inhibitor cocktail from Sigma, $1 \mathrm{mM}$ $\mathrm{NaF}$; pH 7.4). Cells were incubated in ice for $30 \mathrm{~min}$ with vortexing every 10 minutes and then centrifuged at $15,000 \times \mathrm{g}$ at $4^{\circ} \mathrm{C}$ for $10 \mathrm{~min}$. Five $\mu \mathrm{l}$ of the extract were used to determine protein concentration by the Bradford assay (Bio-Rad). The extracts were frozen in liquid $\mathrm{N}_{2}$ and stored at $-80^{\circ} \mathrm{C}$. Different amounts of total extracts were resolved on SDS 15\%-polyacrylamide gels. After protein transference using a semidry electroblotter, PVDF membranes (Immobilon P, Millipore) were incubated with an antibody against S100A4 (DAKO), and detection was accomplished by secondary horseradish peroxidase-conjugated antibody and enhanced chemiluminescence, as recommended by the manufacturer (Amersham). To normalize the results, blots were re-probed with antibodies against either Actin or GAPDH (Sigma).

\section{Transfection of an expression vector encoding for S100A4}

Cells were seeded into 6-well plates in $1 \mathrm{ml}$ of HAM's F12 selective medium. Eighteen hours later, cells were transfected with the expression plasmid for S100A4 (pCMV6XL5-S100A4, OriGene Technologies; abbreviated in the manuscript as pCMV-S100A4), using either Lipofectamine $^{\mathrm{Tm}} 2000$ (Invitrogen) or Fugene (Roche) following the manufacturer's specifications. The overexpression of S100A4 was monitored by determining its mRNA levels after $48 \mathrm{~h}$ and by determining its protein levels after $72 \mathrm{~h}$ upon transfection, respectively. When assaying the sensitivity to MTX caused by overexpression of S100A4, MTX was added $48 \mathrm{~h}$ upon transfection and cell viability determined using the MTT assay 6 days after MTX addition. An empty vector was transfected in parallel with pCMVS100A4 and was used as negative control.

\section{ELISA assay}

Cells were transfected with pCMV-S100A4 as described above and cell culture media was collected $72 \mathrm{~h}$ after transfection. Sandwich ELISA was performed in MaxiSorb plates (NUNC), coated with a mouse anti-S100A4 antibody $\mathrm{O} / \mathrm{N}$ at $4^{\circ} \mathrm{C}$. Blocking was performed with $1 \%$
BSA for $1 \mathrm{~h}$ at $37^{\circ} \mathrm{C}$. Incubation with the samples was performed for $2.5 \mathrm{~h}$ at $37^{\circ} \mathrm{C}$, followed by incubation with a rabbit anti-S100A4 antibody. Finally, incubation with a secondary goat anti-rabbit horseradish peroxidase-conjugated antibody was performed for $1 \mathrm{~h}$ at $37^{\circ} \mathrm{C}$. Reading of absorbance upon TMB addition was performed in a Multiskan Ascent (Thermo) plate-reading spectrophotometer at $630 \mathrm{~nm}$. Background signal was determined in parallel and was used to correct the absorbance values. All analyses were performed at least in duplicate for each sample in each experiment.

\section{Transfection of siRNAs against S100A4 RNA}

HT29 cells were plated in $1 \mathrm{ml}$ of -GHT medium. Transfection was performed eighteen hours later with a siRNA designed against S100A4 RNA (siS100A4) or with a siS100A4-4 MIS bearing 4 mismatches with respect to siS100A4 (underlined in the sequence below).

siS100A4: 5'-CAGGGACAACGAGGTGGAC-3' siS100A4-4 MIS: 5'-CACCCTCAACGAGGTGGAC3'

Cells were lipofected with the siRNAs using Lipofectamine $^{\mathrm{Tm}} 2000$ (Invitrogen) in accordance to the manufacturer's instructions. MTX $\left(10^{-7} \mathrm{M}\right)$ was added 48 hours after siRNA treatment and MTT assays were performed as described previously [15] after 5 days from the treatment with the siRNA. S100A4 knockdown was monitored by determining its mRNA levels after $48 \mathrm{~h}$ and its protein levels after $72 \mathrm{~h}$ upon siRNA transfection, respectively.

The siRNAs were designed using the software iRNAi v2.1. Among the possible alternatives, sequences rich in $\mathrm{A} / \mathrm{T}$ on the 3 ' of the target were chosen. Then, BLAST resources in NCBI [16] were used to assess the degree of specificity of the sequence recognition for these siRNAs. We selected the siRNA that reported the target gene as the only mRNA hit. To further assess siRNA specificity for S100A4, we determined the mRNA levels of Enolase 2, Topoisomerase II, Clusterin and UGT1A7 upon incubation with siS100A4 (off-target effects) by Real-Time PCR using SYBR Green dye. See Additional file 1: Primers for off-target effects determination.

Transfection of an expression vector encoding for $\beta$-catenin Cells were seeded into 6-well plates. Eighteen hours later, transfection with the expression plasmid for $\beta$-catenin (pcDNA3- $\beta$-catenin) kindly provided by Dr. Duñach, Universitat Autònoma de Barcelona, Spain) was performed as described for pCMV-S100A4. Cells were collected $48 \mathrm{~h}$ after transfection for RNA determination. S100A4 mRNA levels were monitored by RT-Real-Time PCR. The empty vector was transfected in parallel with pcDNA3- $\beta$-catenin and was used as negative control. 


\section{Statistical analyses}

Data are presented as mean \pm SE. Statistical analyses were performed using the unpaired t test option in GraphPad InStat version 3.1a for Macintosh. p-values of less than 0.05 were considered statistically significant.

\section{Results \\ S100A4 is overexpressed but not amplified in human cells resistant to methotrexate}

In previous studies, we used the HG U133 PLUS 2.0 microarrays from Affymetrix as a tool to analyze the differential gene expression between sensitive and MTXresistant cells derived from different human cell lines representative of colon cancer (HT29 and $\mathrm{CaCo}-2$ ), breast cancer (MCF-7 and MDA-MB-468), pancreatic cancer (MIA PaCa-2), erythroblastic leukemia (K562) and osteosarcoma (Saos-2) (GEO series accession number [GSE16648], which also contains the current data). Now we performed a global analysis of the seven cell lines to find out genes differentially expressed in at least four out of the seven cell lines. The list of these genes is provided in Table 1. Among them, S100A4 was a gene differentially expressed in five out of the seven cell lines and previously reported to have a role in chemotherapy resistance [13]. We validated S100A4 overexpression in HT29, MCF-7, MIA PaCa-2, K562 and Saos-2 resistant cell lines at the levels of mRNA and protein, and determined that S100A4 upregulation in the resistant cells was not due to changes in its gene copy number (Table 2).

\section{Ectopic overexpression of S100A4 desensitizes HT29 cells toward MTX}

HT29 MTX-resistant cells displayed the highest S100A4 expression values, considering both the mRNA and protein levels (Table 2). Thus, HT29 cells were selected for further studies using an expression vector for S100A4 (pCMV-S100A4). Transfection with $250 \mathrm{ng}$ of this vector produced a 8-fold increase in the levels of S100A4 RNA after 48 hours (Figure 1A). The intracellular levels of S100A4 protein were also increased, reaching almost 5 fold when transfecting $1 \mu \mathrm{g}$ of the expression plasmid (Figure 1B). The overexpression of S100A4 was associated to a decrease in the sensitivity toward MTX (Figure $1 C)$.

\section{S100A4 is secreted by HT29 cells transfected with pCMV- S100A4}

Given that it had been described that S100A4 has extracellular functions [12,17], we explored S100A4 protein levels in the culture media of pCMV-S100A4 transfected cells. The results from the ELISA assays showed increased amounts of S100A4 protein in media from transfected cells (Figure 1D), thus indicating that a frac- tion of the protein produced upon vector transfection was secreted outside the cells.

\section{Knocking down S100A4 with siRNA chemosensitizes HT29 toward MTX}

We used iRNA technology to study the role of S100A4 in MTX resistance. Treatment of sensitive HT29 cells with increasing concentrations $(10-100 \mathrm{nM})$ of the siRNA against S100A4 (siS100A4) showed a progressive decrease in its mRNA levels (Figure 2A), causing an $80 \%$ reduction at $100 \mathrm{nM}$. This treatment also caused a vast decrease in S100A4 protein levels (Figure 2B) and increased the sensitivity of HT29 cells toward MTX by about $50 \%$ (Figure $2 \mathrm{C}$ ). To further assess siRNA specificity for S100A4, we determined the mRNA levels of other cellular genes upon incubation with siS100A4 (off-target effects). These experiments did not show any significant variation of the mRNA levels for Enolase 2, Topoisomerase II, Clusterin and UGT1A7 (Table 3)

Treatment with $100 \mathrm{nM}$ siS100A4 was also performed in HT29 MTX-resistant cells. This approach led to a reduction of $75 \%$ in the levels of S100A4 RNA (Figure 3A) but had no effect on cell viability (Figure 3B). A 4-mismatch siRNA against S100A4 (siS100A4-4 MIS) was used as negative control, and did not cause any significant effects on S100A4 mRNA, protein levels or cell viability, in neither of the two cell lines.

\section{S100A4 is transcriptionally regulated by the Wnt pathway in $\mathrm{HT} 29$ cells}

It had been previously described that S100A4 was a target of the Wnt signaling pathway and a functional TCF binding site has been identified in its promoter sequence [18]. To investigate whether S100A4 expression was regulated through this pathway in HT29 cells, we overexpressed $\beta$ catenin in HT29 sensitive or resistant cells and quantified S100A4 mRNA levels $48 \mathrm{~h}$ after transfection. A 2-fold increase in S100A4 mRNA levels was observed upon transfection of $1 \mu \mathrm{g}$ of pcDNA3- $\beta$-catenin in HT29 sensitive cells (Figure 4A) whereas no changes were obtained when transfection was performed in HT29 resistant cells (Figure 4B).

\section{Discussion}

The principal aim of this work was to find out genes differentially expressed in cell lines resistant to MTX representative of five different types of human cancer. In a previous report [3], we determined and compared the patterns of differential gene expression associated to MTX resistance in seven human cancer cell lines. In that work, we established that the only differentially expressed gene in common among all the cell lines studied was DHFR. In the present work, we identified genes differentially expressed in at least four out of the seven cell lines 
Table 1: Genes differentially expressed in at least four out of the seven MTX-resistant cell lines studied.

\begin{tabular}{|c|c|c|c|c|c|c|c|c|c|}
\hline \multirow[t]{2}{*}{ Genbank } & \multirow[t]{2}{*}{ Gene Name } & \multirow[t]{2}{*}{ Description } & \multicolumn{7}{|c|}{ Fold Change } \\
\hline & & & HT29 & Caco-2 & MCF-7 & $\begin{array}{l}\text { MDA- } \\
\text { MB-468 }\end{array}$ & $\begin{array}{c}\text { MIA } \\
\text { PaCa-2 }\end{array}$ & K562 & SaOs-2 \\
\hline$\underline{\mathrm{U} 05598}$ & AKR1C2 & aldo-keto reductase family 1 , member $\mathrm{C} 2$ & 4.6 & 10.2 & 0.03 & 31.1 & 0.02 & 5.0 & NS \\
\hline$\underline{A B 018580}$ & AKR1C3 & aldo-keto reductase family 1 , member $\mathrm{C} 3$ & 1.8 & 4.6 & 0.8 & 73.3 & 0.7 & 12.0 & NS \\
\hline NM 000691 & ALDH3A1 & aldehyde dehydrogenase 3 family, member $\mathrm{A} 1$ & 2.9 & 3.8 & 6.6 & 11.9 & 0.4 & NS & NS \\
\hline AL136912 & ATG10 & ATG10 autophagy related 10 homolog & 8.7 & NS & NS & 1.5 & 2.1 & 10.1 & 2.0 \\
\hline$\underline{\text { U36190 }}$ & CRIP2 & cysteine-rich protein 2 & 2.7 & 1.3 & 1.9 & NS & 2.2 & NS & 0.3 \\
\hline NM 001321 & CSRP2 & cysteine and glycine-rich protein 2 & 2.0 & 0.3 & 2.7 & NS & 2.0 & 2.9 & 0.5 \\
\hline$\underline{\text { AU144855 }}$ & CYP1B1 & $\begin{array}{l}\text { cytochrome } \mathrm{P} 450 \text {, family } 1 \text {, subfamily } B \text {, } \\
\text { polypeptide } 1\end{array}$ & 3.1 & 2.3 & 0.5 & NS & 4.2 & NS & 0.4 \\
\hline Al144299 & DHFR & dihydrofolate reductase & 7.3 & 50.2 & 52.8 & 1.8 & 16.9 & 17.8 & 8.9 \\
\hline$\underline{\text { AA578546 }}$ & DHFRL1 & dihydrofolate reductase-like 1 & 7.0 & 10.8 & 5.5 & NS & 3.0 & 17.5 & 2.1 \\
\hline NM 012242 & DKK1 & dickkopf homolog 1 (Xenopus laevis) & 4.3 & 2.5 & 2.1 & NS & 0.7 & NS & 19.1 \\
\hline Al745624 & ELL2 & elongation factor, RNA polymerase II, 2 & NS & 1.7 & 0.4 & 2.6 & 8.0 & 2.3 & 2.7 \\
\hline AF052094 & EPAS1 & endothelial PAS domain protein 1 & 2.8 & NS & 2.4 & NS & 6.4 & 0.4 & 0.1 \\
\hline$\underline{\mathrm{AU} 144565}$ & EPB41L4A & $\begin{array}{l}\text { erythrocyte membrane protein band } 4.1 \text { like } \\
4 A\end{array}$ & 1.6 & 1.3 & 1.7 & 1.4 & 2.3 & 4.4 & 4.7 \\
\hline$\underline{\text { AW246673 }}$ & FAM46A & family with sequence similarity 46 , member $A$ & NS & 2.6 & NS & NS & 3.9 & 2.5 & 1.5 \\
\hline NM 000142 & FGFR3 & fibroblast growth factor receptor 3 & NS & 4.6 & 3.1 & 0.4 & 1.5 & 0.4 & 3.4 \\
\hline NM 018071 & FL10357 & hypothetical protein FLJ10357 & NS & 3.8 & NS & NS & 2.1 & 3.2 & 3.5 \\
\hline BE550452 & HOMER1 & homer homolog 1 (Drosophila) & NS & NS & 27.9 & NS & 2.4 & 13.8 & NS \\
\hline AF243527 & KLK5 & kallikrein-related peptidase 5 & 2.3 & NS & 2.2 & NS & 3.5 & NS & 4.6 \\
\hline AK022625 & LOC92270 & V-type proton ATPase subunit S1-like protein & 54.0 & 2.3 & NS & NS & 3.4 & 25.0 & NS \\
\hline$\underline{\mathrm{BC} 006471}$ & MLLT11 & myeloid/lymphoid or mixed-lineage leukemia & 2.2 & 2.6 & NS & NS & 1.8 & 0.08 & 1.7 \\
\hline NM 002439 & MSH3 & mutS homolog 3 (E. coli) & 6.3 & 8.2 & 3,8 & NS & 13.2 & 35.9 & 1,5 \\
\hline NM 006117 & $\mathrm{PECl}$ & peroxisomal D3, D2-enoyl-CoA isomerase & 7.5 & 2.6 & 1.9 & NS & NS & NS & 1.8 \\
\hline
\end{tabular}


Table 1: Genes differentially expressed in at least four out of the seven MTX-resistant cell lines studied. (Continued)

\begin{tabular}{|c|c|c|c|c|c|c|c|c|c|}
\hline BF432873 & PSMD11 & proteasome $26 \mathrm{~S}$ subunit, non-ATPase, 11 & NS & 2.3 & NS & NS & 1.3 & 3.5 & 1.4 \\
\hline NM 002923 & RGS2 & regulator of G-protein signaling 2, $24 \mathrm{kDa}$ & 1.6 & 8.2 & 3.6 & NS & 3.2 & 1.9 & NS \\
\hline AW043594 & RPS23 & ribosomal protein $\mathrm{S} 23$ & 12.9 & NS & NS & NS & 2.9 & 8.9 & 1.8 \\
\hline NM 005978 & $\mathrm{~S} 100 \mathrm{~A} 2$ & S100 calcium binding protein $\mathrm{A} 2$ & 0.5 & 0.3 & 7.1 & NS & 4.0 & NS & 4.1 \\
\hline NM 002961 & S100A4 & S100 calcium binding protein A4 & 3.7 & 0.6 & 4.3 & NS & 2.4 & 1.5 & 2.5 \\
\hline$\underline{A L 565362}$ & SLC2A13 & solute carrier family 2 , member 13 & 4.0 & 9.4 & 0.6 & 2.5 & 4.3 & 10.2 & NS \\
\hline BG150485 & SLC6A6 & solute carrier family 6 , member 6 & 0.6 & 2.6 & 2.2 & NS & 2.4 & 1.5 & 1.5 \\
\hline NM 003069 & SMARCA 1 & $\begin{array}{l}\text { SWI/SNF related, matrix associated, actin } \\
\text { dependent regulator of chromatin, subfamily } \\
\text { A, member } 1\end{array}$ & 2.6 & 2.6 & 14.0 & NS & NS & 3.4 & 1.7 \\
\hline NM 012446 & SSBP2 & single-stranded DNA binding protein 2 & 10.6 & NS & 0.5 & NS & 2.9 & 5.0 & 2.0 \\
\hline AW134979 & STXBP6 & syntaxin binding protein 6 (amisyn) & NS & 2.1 & 27.5 & NS & 3.0 & 14.5 & 0.5 \\
\hline NM 003248 & THBS4 & thrombospondin 4 & NS & 12.9 & 9.2 & NS & 15.7 & 4.9 & 0.6 \\
\hline$\underline{B E 873420}$ & UGT1A6 & $\begin{array}{l}\text { UDP glucuronosyltransferase 1, polypeptide } \\
\text { A6 }\end{array}$ & NS & 2.8 & 24.4 & 27.9 & 5.3 & NS & NS \\
\hline Al922599 & VIM & vimentin & 2.4 & NS & 3.6 & NS & NS & 4.9 & 1.7 \\
\hline BE539792 & ZCCHC9 & zinc finger, $\mathrm{CCHC}$ domain containing 9 & 8.3 & 1.5 & 0.5 & NS & 6.7 & 7.9 & NS \\
\hline BU078629 & ZFYVE16 & zinc finger, FYVE domain containing 16 & 6.1 & 45.8 & 76.4 & NS & 16.5 & 23.1 & 3.2 \\
\hline
\end{tabular}

A global comparison analysis was performed to find out differentially expressed genes in the majority of the MTX-resistant cells. The table includes the list of the genes differentially expressed in at least four out of the seven MTX-resistant cell lines that displayed a Benjamini-Hochberg false discovery rate-corrected $p$-value $<0.05$. For each gene, the Genbank accession number, gene name, description and fold change in each resistant cell line with respect to its respective sensitive counterpart are shown. All values displayed are significant, unless otherwise stated (NS, non significant; p-value > 0.05)

studied. Among the genes that fulfilled this requisite, we found some genes that we had previously validated and reported to be directly associated with MTX resistance in HT29 MTX-resistant cells (DHFR, AKR1C1 and DKK1) or suggested to contribute to the phenotype in this cell line (MSH3, SSBP2 and ZFYVE16) [3-5]. We also found UGT1A6, a gene that seems to play a role in MTX resistance in MCF-7 and in MDA-MB-468 cells (data not shown). Among the other genes in the list, we selected, for expression, genomic and functional validation, S100A4, a gene overexpressed in five out of these seven cell lines that was the only one previously reported to be associated with chemoresistance [13]. This gene has also been related with malignancy, metastasis, and tumor progression.

The human S100A4 is a member of the S100 family of EF-hand $\mathrm{Ca}^{2+}$-binding proteins. The multigenic family of S100 proteins is expressed in vertebrates exclusively and has been described to play intracellular and extracellular regulatory activities on protein phosphorylation, on the dynamics of cytoskeleton components or on $\mathrm{Ca}^{2+}$ homeostasis $[8,9]$. S100A4 in particular has been described to have a function in cell cycle progression, in cell motility and as a modulator of intercellular adhesion and of the 
Table 2: Validation of S100A4 overexpression and copy number determination in the different cell lines.

\begin{tabular}{|c|c|c|c|c|c|c|}
\hline \multirow[t]{3}{*}{ Cell Line } & \multicolumn{4}{|c|}{ Expression } & \multirow[b]{3}{*}{ Copy-number } & \multirow[b]{3}{*}{ Protein } \\
\hline & \multicolumn{3}{|c|}{ Microarray } & \multirow[b]{2}{*}{ RT-PCR Validation } & & \\
\hline & Signal Sensitive & Signal Resistant & Ratio & & & \\
\hline HT29 & 1876 & 6862 & 3.7 & $6.2 \pm 0.2$ & $1.4 \pm 0.1$ & $22.5 \pm 1.0$ \\
\hline MCF-7 & 49 & 213 & 4.3 & $6.2 \pm 0.3$ & $1.5 \pm 0.1$ & $10.8 \pm 2.2$ \\
\hline MiaPaCa-2 & 3304 & 7925 & 2.4 & $4.7 \pm 0.6$ & $1.2 \pm 0.1$ & $24.4 \pm 8.1$ \\
\hline K562 & 147 & 249 & 1.5 & $3.6 \pm 0.2$ & $1.6 \pm 0.1$ & $4.0 \pm 1.0$ \\
\hline Saos-2 & 137 & 345 & 2.5 & $2.2 \pm 0.1$ & $2.16 \pm 0.07$ & $2 \pm 0.4$ \\
\hline $\mathrm{CaCo}-2$ & 4515 & 2769 & 0.6 & $\mathrm{~N} / \mathrm{D}$ & $\mathrm{N} / \mathrm{D}$ & N/D \\
\hline $\begin{array}{c}\text { MDA-MB- } \\
468\end{array}$ & 317 & 235 & 0.7 & N/D & N/D & N/D \\
\hline
\end{tabular}

invasive properties of cells $[9,19]$ (see Sherbet et al. for a review [20]). Several cancers, including colon cancer, breast cancer and osteosarcoma, are known to produce S100A4 [10], and particularly, HT29 cells have been described to express a substantial amount of S100A4 [21]. Overexpression of S100A4 is more frequently found in cancer cells than in normal colonic mucosa, as well as more in liver metastasis than in primary tumors [21]. A correlation between S100A4 expression levels and the invasive potential of HT29 cells has been suggested [21]. S100A4 gene overexpression has been related to the malignant potential of some tumors [10] and has been closely associated with metastasis in several human cancers, including colorectal [21], breast [22,23], ovary [24], thyroid [25], pancreatic [26], lung [27,28], esophageal [29], prostate [30] and gastric cancer [31,32].

We tried to mimic the overexpression of S100A4 in the resistant cells by transfecting HT29 sensitive cells with an expression vector encoding for S100A4. We tested that S100A4 mRNA and intracellular protein levels were significantly increased after transfection. Importantly, we could observe a reversion of the cytotoxicity caused by MTX upon transfection with S100A4 expression vector. It is worth mentioning that a moderate S100A4 overexpression has been described in a colon cancer cell line resistant to doxorubicin [33]. S100P, another member of the S100 family, has also been related to doxorubicin resistance in colon cancer [33]. Moreover, S100A4 expression has been detected in patients that had received adjuvant 5-fluorouracil, and has been proposed to be a predictive factor of relapse in gastric cancer [34]. Likewise, S100P overexpression has been reported to promote pancreatic cancer growth and increase cell survival after 5-fluorouracil exposure [35].

To investigate the role of intracellular S100A4 on MTX resistance, we used iRNA technology. Transfection of a siRNA against S100A4 in HT29 MTX-resistant cells caused a reduction in gene RNA levels but did not alter cell viability. The latter effect could be explained by the overexpression by gene amplification of the $d h f r$ locus in this resistant cell line, which would mask the effects of the siRNA used. However, when the same treatments were performed in HT29 sensitive cells, carrying no $d h f r$ amplification, we could achieve a chemosensitization of these cells toward MTX. These latter results are in agreement with Mahon et al. [13] that showed that inhibition of S100A4 expression resulted in an increased sensitivity of pancreatic ductal adenocarcinoma cell lines to gemcitabine treatment and induced apoptosis. It has also been described that S100A4 knockdown enhances the sensitiv- 
A

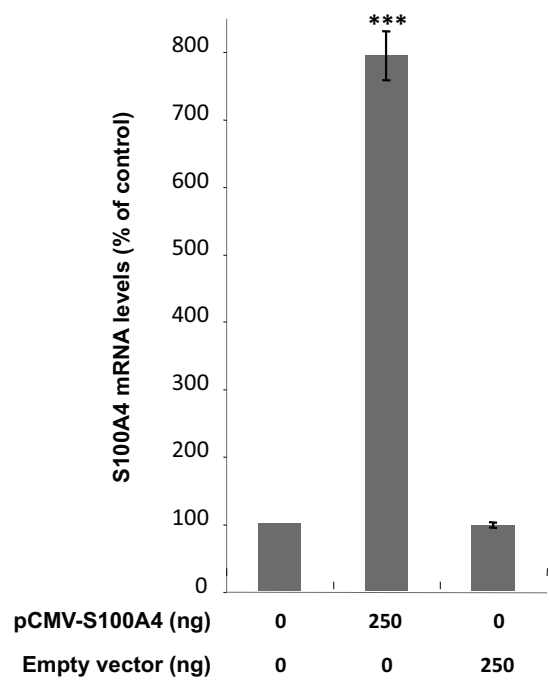

C

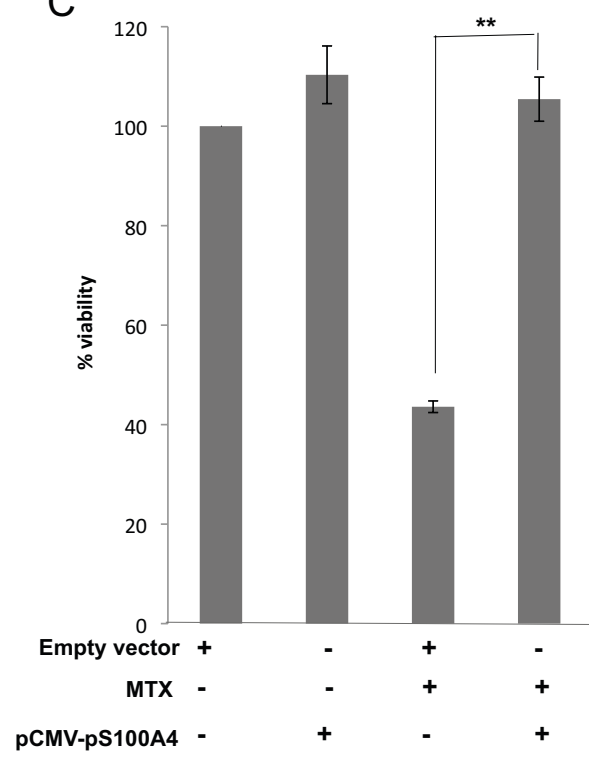

B
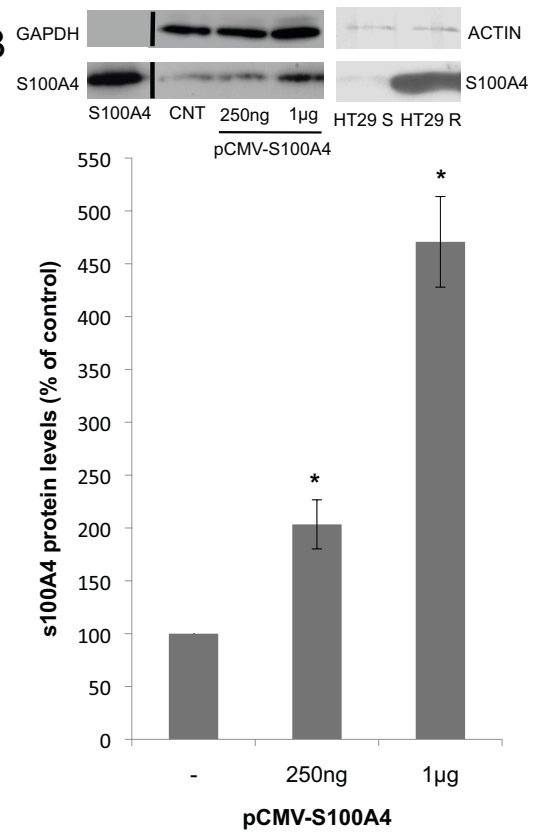

D

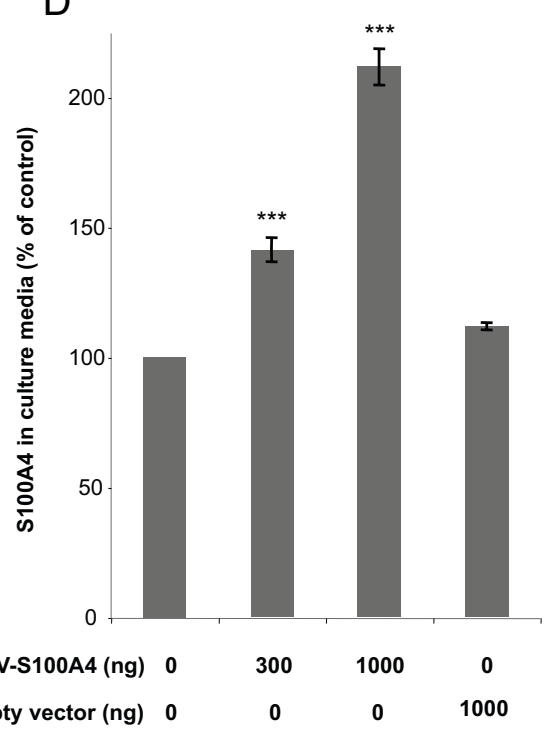

Figure 1 Effects on S100A4 expression and MTX sensitivity upon pCMV-S100A4 transfection of HT29 cells. A) mRNA levels of S100A4 determined by RT-Real-Time PCR $48 \mathrm{~h}$ after treatment of HT29 cells $(30,000)$ with $250 \mathrm{ng}$ of the expression vector for S100A4 (pCMV-S100A4). B) A representative image of the intracellular protein levels of S100A4 determined by Western Blotting $72 \mathrm{~h}$ after ectopic transfection with its expression vector is shown in the upper panel, and the quantification of the blots is shown in the lower panel. Purified S100A4 protein was used as a reference marker (Abnova; first lane). An additional panel showing endogenous S100A4 protein levels in HT29 sensitive (S) and resistant (R) cells is also provided. C) Effects of S100A4 overexpression on cell viability. HT29 cells $(100,000)$ were treated with $1 \mu \mathrm{g}$ of pCMV-S100A4 and $5 \times 10^{-8} \mathrm{M}$ MTX was added $48 \mathrm{~h}$ later. Cell viability was assessed by the MTT assay six days after MTX treatment. D) Extracellular S100A4 protein levels quantified by ELISA $72 \mathrm{~h}$ after S100A4 overexpression upon PCMV-S100A4 transfection. The expression and viability results are expressed as percentages referred to the untreated cells. Values are the mean of three independent experiments \pm SE. ${ }^{*} p<0.05,{ }^{* *} p<0.01,{ }^{* * *} p<0.001$. 
Table 3: Assessment of siS100A4 specificity.

\begin{tabular}{cccccc}
\hline Gene & S100A4 & Enolase 2 & Topoisomerase II & Clusterin & UGT1A7 \\
\hline Control & 100 & 100 & 100 & 100 & 100 \\
SiRNA & $18.6 \pm 6$ & $135.8 \pm 21.6$ & $127.5 \pm 6.4$ & $133.9 \pm 14.4$ & $159.5 \pm 28.4$ \\
S100A4 & & & & & \\
\hline
\end{tabular}

HT29 cells were transfected with $100 \mathrm{nM}$ siS100A4. Forty-eight hours later, the mRNA levels of S100A4 and four unrelated genes were determined by RT-Real-Time PCR. Data represent the mean of three experiments \pm SE.

ity of osteocarcinoma cells to undergo apoptosis [36] and reverses the metastatic potential of osteosarcoma [37] and lung carcinoma cells [28]. These reports together

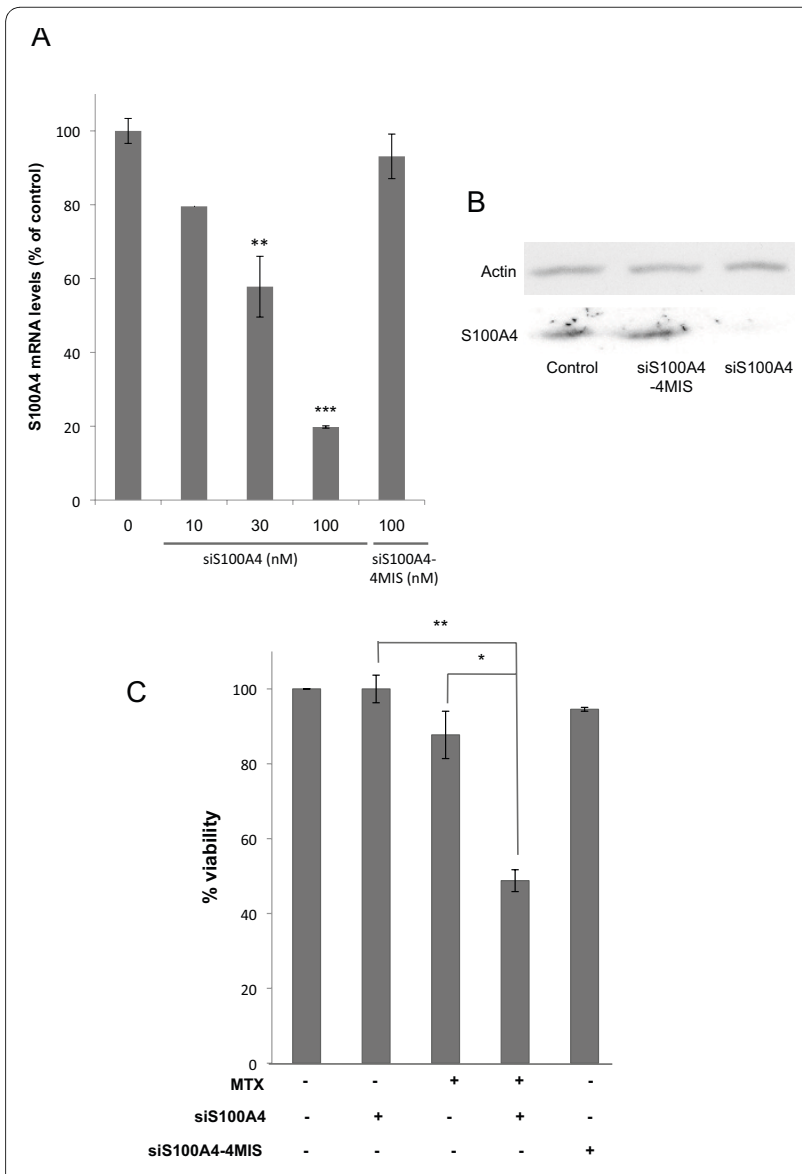

Figure 2 Effects on S100A4 expression and MTX sensitivity upon siS100A4 transfection of HT29 cells. A) HT29 cells $(30,000)$ were transfected with siS100A4 as described in Methods. Total RNA was extracted after $48 \mathrm{~h}$ and S100A4 mRNA levels were determined by RTReal-Time PCR. B) S100A4 protein levels were determined by Western Blotting $72 \mathrm{~h}$ after transfection, using specific antibodies against S100A4 and Actin to normalize the results. C) Chemosensitization assays toward methotrexate: cells were treated with siS100A4 for $48 \mathrm{~h}$ and then incubated with MTX. Cell viability was determined 3 days after MTX treatment. The expression and viability results are expressed as percentages referred to the untreated cells. Values are the mean of three independent experiments $\pm \mathrm{SE}$. A representative image of Western Blots is presented. ${ }^{*} p<0.05,{ }^{* *} p<0.01,{ }^{* * *} p<0.001$. with our results using either the expression vector or siRNA technology, provide evidence that S100A4 acts as a pro-survival factor that contributes, together with DHFR, AKR1C1 and DKK1 (see above), to chemoresistance in HT29 MTX-resistant cells. S100A4 could be considered as biomarker of resistance in the sense that it is overexpressed in the majority of the resistant cell lines analyzed, and its determination is easy to perform. In addition it could be considered as a drug target in the category of resistance modulator using inhibitors of S100A4 as an adjuvant in MTX treatment.

In an attempt to determine the mechanism for the overexpression of S100A4 in HT29 resistant cells, we determined S100A4 copy number in both HT29 cell lines. Although it has been previously described that the chromosomal region where the gene is located (1q21) is amplified in breast cancer [38,39] and in tumor tissue from osteosarcoma patients [40], we did not observe copy number changes for S100A4 in any of the cell lines studied. Other mechanisms have been proposed that attempt to explain the mechanism for S100A4 overexpression: i) by hypomethylation, since increased S100A4 expression levels have been associated with decreased methylation of the first intron of this gene in cell lines and carcinomas of pancreatic origin [26] and of the second intron in colon cancer cell lines [41]; and ii) through the Wnt signaling pathway, given that it has been shown that S100A4 is a target of this pathway in colon cancer and a functional TCF binding site has been identified in its promoter sequence [18]. In this sense, we had previously proposed the activation of the Wnt/ $\beta$-catenin pathway to be an important step in MTX resistance in HT29 colon cancer cells [5]. In this cell line, E-cadherin is lost at the chromosome level and underexpressed, thus allowing $\beta$-catenin to play its function in gene transcription. In this direction, an inverse correlation has been established between the expression levels of S100A4 and E-Cadherin [42] and has been associated with poor differentiation of cancer cells [31]. Moreover, transfection of an E-Cadherin expression vector has been reported to cause a decrease in S100A4 expression levels [43]. To further elucidate if the Wnt signaling pathway could be responsible for the increased expression levels of S100A4 in the resistant cells, we overexpressed $\beta$-catenin and determined 


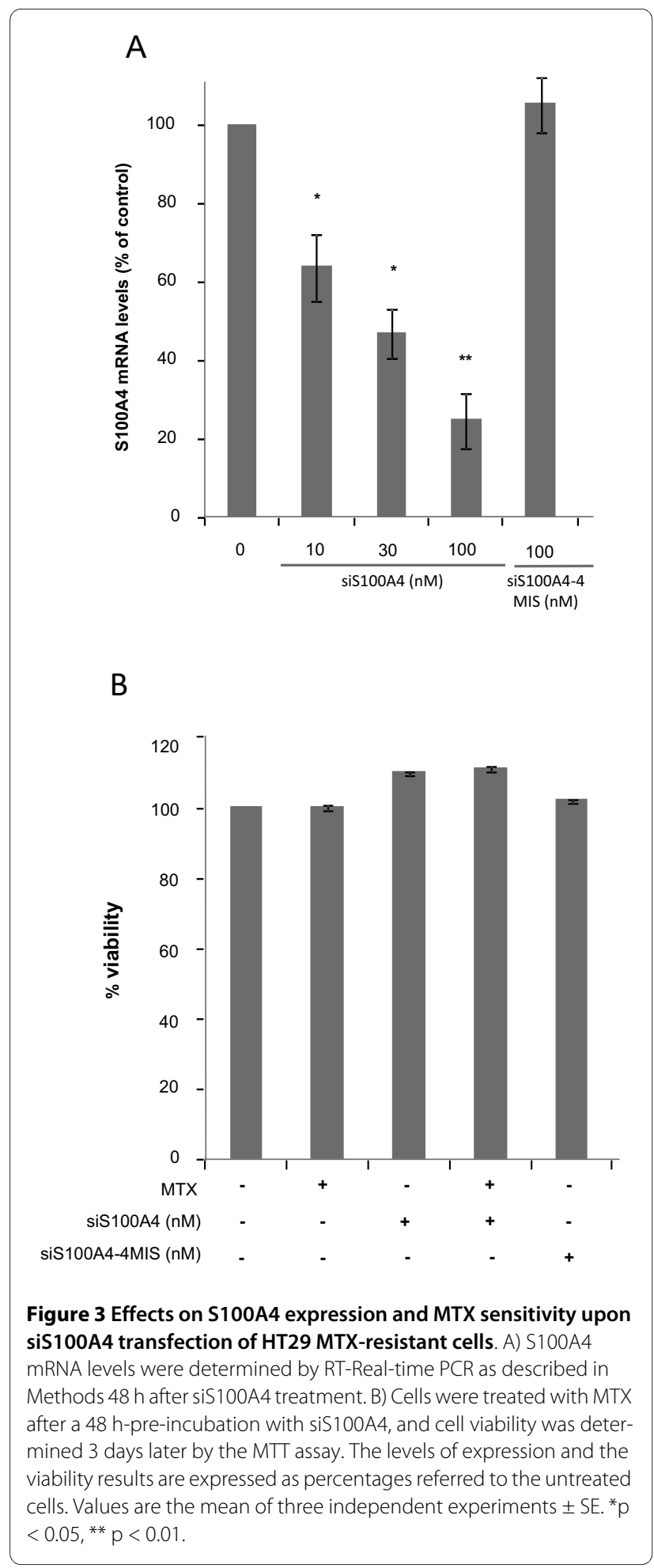

S100A4 mRNA levels. The resistant cells, which already have the Wnt/ $\beta$-catenin pathway highly activated, do not respond to $\beta$-catenin overexpression. However, the results obtained in HT29 sensitive cells showing a twofold increase in S100A4 mRNA expression upon $\beta$ catenin transfection give support to a $\mathrm{Wnt} / \beta$-catenin

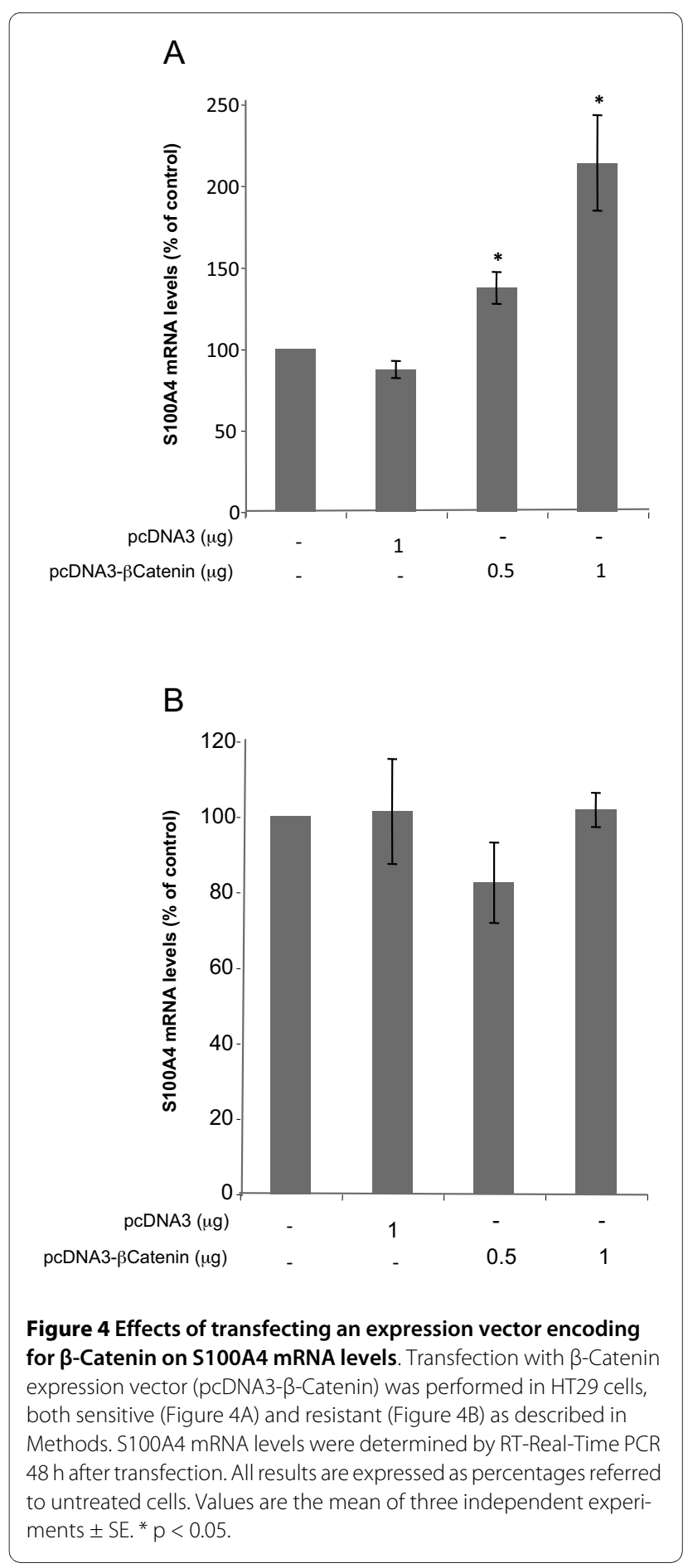

pathway-mediated S100A4 transcription. Another target of the Wnt signaling pathway that had been previously related with MTX resistance is P-glycoprotein [44,45]. However, no changes in its expression levels were evidenced by our microarray results in HT29 cells (data not shown).

Although many biological functions have been attributed to S100A4, the exact molecular mechanisms by 
which S100A4 exerts these functions have not been fully elucidated [46]. Extracellular S100A4 has been related to metastasis and angiogenesis $[17,47,48]$ and has been reported to activate NF- $\mathrm{kB}$ signaling. S100A4-mediated activation of NF-kB has been proposed to repress the expression of BNIP3, a pro-apoptotic member of the Bcl2 family, leading to decreased apoptosis [13] and increased resistance to chemotherapy [49]. Our ELISA experiments demonstrated that S100A4 ectopic overexpression in the sensitive cells leads to the secretion of a fraction of the synthesized protein. Secretion of S100A4 by tumor cells has been previously demonstrated in vitro [12]. One can hypothesize that secreted S100A4 would contribute to resistance through BNIP3 regulation by the NF- $k B$ pathway in HT29 cells. However, our microarray results show no changes in BNIP3 expression levels in HT29 resistant cells (data not shown), thus suggesting that this gene does not play a role in chemoresistance in this cell line.

S100A4 has been reported to interact with p53, thus interfering in p53 activation and DNA binding capacity [50]. Mutations in p53 are frequently found in colorectal cancer [51], and HT29 cells bear mutations in this gene. These mutations reduce p53-dependent responses, thus allowing the cells to continue to proliferate and therefore give rise to drug resistance $[52,53]$. To further establish MTX resistance, interaction between p53 and S100A4 would be necessary to reduce p53 remaining activity. The significant 2-fold decrease in p53 expression levels in HT29 resistant cells shown in our microarray results, in accordance with others [54], would lead to increased proliferation and reduced apoptosis, both of which would contribute to MTX resistance.

In summary, our results show a role for S100A4 in MTX resistance. Its overexpression in HT29 MTX-resistant cells is not due to changes in gene copy-number but to a transcriptional regulation, probably through the Wnt pathway. Cellular knockdown of S100A4 leads to chemosensitization toward MTX and ectopic gene overexpression desensitizes the cells toward this chemotherapeutic agent.

\section{Conclusions}

S100A4 was identified and confirmed as a gene overexpressed in five out of the seven MTX-resistant cell lines studied. S100A4 ectopic overexpression in HT29 cells lead to a desensitization toward MTX. Conversely, transfection experiments using interference RNA produced a chemosensitization to MTX. The results obtained in this report establish a relation between S100A4 and resistance to MTX.

\section{Additional material}

Additional file 1 Primers for off-target effects determination. The word table shows the sequences of the primers used to assess the off-target effects of transfected siS100A4 by determining the mRNA levels of Enolase 2, Topoisomerase II, Clusterin and UGT1A7 by RT-Real-Time PCR. APRT mRNA was used to normalize the results.

\section{Abbreviations}

MTX: methotrexate; DHFR: dihydrofolate reductase; S100A4: S100 calcium binding protein A4.

\section{Competing interests}

The authors declare that they have no competing interests.

\section{Authors' contributions}

NM, ES, CA, XV, IR, JA, SR, and JLH performed the experimental work. ES and CJC analyzed the data. VN and CJC designed the study, helped with data interpretation and supervised the experimental work. All authors wrote and approved the final manuscript.

\section{Acknowledgements}

This work was supported by grant SAF08-00043 from "Plan Nacional de I+D+I", and ISCIII-RETIC RD06/0020. Our research group holds the "quality distinction" from the "Generalitat de Catalunya" SGR09-118. N.M.is a recipient of a APIF fellowship from the University of Barcelona, E.S. of a FPU fellowship from the "Ministerio de Ciencia y Tecnología" (MCYT) and CA of a FI fellowship from the "Generalitat de Catalunya".

\section{Author Details}

1Department of Biochemistry and Molecular Biology, School of Pharmacy, University of Barcelona, Diagonal Avenue 643, Barcelona, Spain and 2Leitat Technological Center (Biomed Division), Helix building PCB, Barcelona, Spain

Received: 21 October 2009 Accepted: 1 June 2010

Published: 1 June 2010

\section{References}

1. Chu E, Grem JL, Johnston PG, Allegra CJ: New concepts for the development and use of antifolates. Stem Cells 1996, 14:41-46.

2. Jolivet J, Cowan KH, Curt GA, Clendeninn NJ, Chabner BA: The pharmacology and clinical use of methotrexate. N Engl J Med 1983, 309:1094-1104.

3. Selga E, Oleaga C, Ramirez S, de Almagro MC, Noe V, Ciudad CJ: Networking of differentially expressed genes in human cancer cells resistant to methotrexate. Genome Med 2009, 1:83.

4. Selga E, Noe V, Ciudad CJ: Transcriptional regulation of aldo-keto reductase $1 \mathrm{C} 1$ in $\mathrm{HT} 29$ human colon cancer cells resistant to methotrexate: role in the cell cycle and apoptosis. Biochem Pharmacol 2008, 75:414-426.

5. Selga E, Morales C, Noe V, Peinado MA, Ciudad CJ: Role of caveolin 1, Ecadherin, Enolase 2 and PKCalpha on resistance to methotrexate in human HT29 colon cancer cells. BMC Med Genomics 2008, 1:35.

6. Moore BW: A soluble protein characteristic of the nervous system. Biochem Biophys Res Commun 1965, 19:739-744.

7. Dukhanina EA, Dukhanin AS, Lomonosov MY, Lukanidin EM, Georgiev GP: Spectral studies on the calcium-binding properties of Mts1 protein and its interaction with target protein. FEBS Lett 1997, 410:403-406.

8. Donato R: Intracellular and extracellular roles of $\mathrm{S} 100$ proteins. MicrosC Res Tech 2003, 60:540-551.

9. Donato R: S100: a multigenic family of calcium-modulated proteins of the EF-hand type with intracellular and extracellular functional roles. Int J Biochem Cell Biol 2001, 33:637-668.

10. Parker C, Whittaker PA, Usmani BA, Lakshmi MS, Sherbet GV: Induction of $18 A 2 / m t s 1$ gene expression and its effects on metastasis and cell cycle control. DNA Cell Biol 1994, 13:1021-1028.

11. Lloyd BH, Platt-Higgins A, Rudland PS, Barraclough R: Human S100A4 (p9Ka) induces the metastatic phenotype upon benign tumour cells. Oncogene 1998, 17:465-473. 
12. Ambartsumian N, Klingelhofer J, Grigorian M, Christensen C, Kriajevska M, Tulchinsky E, Georgiev G, Berezin V, Bock E, Rygaard J, et al.: The metastasis-associated Mts1(S100A4) protein could act as an angiogenic factor. Oncogene 2001, 20:4685-4695.

13. Mahon PC, Baril P, Bhakta V, Chelala C, Caulee K, Harada T, Lemoine NR: $\mathrm{S} 100 \mathrm{~A} 4$ contributes to the suppression of BNIP3 expression, chemoresistance, and inhibition of apoptosis in pancreatic cancer. Cancer Res 2007, 67:6786-6795.

14. Rocke DM, Durbin B: A model for measurement error for gene expression arrays. J Comput Biol 2001, 8:557-569.

15. Mosmann T: Rapid colorimetric assay for cellular growth and survival: application to proliferation and cytotoxicity assays. $\mathrm{J} / \mathrm{mm}$ monol Methods 1983, 65:55-63.

16. Altschul SF, Gish W, Miller W, Myers EW, Lipman DJ: Basic local alignment search tool. J Mol Biol 1990, 215:403-410.

17. Schmidt-Hansen B, Klingelhofer J, Grum-Schwensen B, Christensen A, Andresen S, Kruse C, Hansen T, Ambartsumian N, Lukanidin E, Grigorian M: Functional significance of metastasis-inducing $\mathrm{S} 100 \mathrm{~A} 4(\mathrm{Mts} 1$ ) in tumorstroma interplay. J Biol Chem 2004, 279:24498-24504.

18. Stein U, Arlt F, Walther W, Smith J, Waldman T, Harris ED, Mertins SD, Heizmann CW, Allard D, Birchmeier W, et al: The metastasis-associated gene S100A4 is a novel target of beta-catenin/T-cell factor signaling in colon cancer. Gastroenterology 2006, 131:1486-1500.

19. Sherbet GV, Lakshmi MS: S100A4 (MTS1) calcium binding protein in cancer growth, invasion and metastasis. Anticancer Res 1998, 18:2415-2421.

20. Sherbet $\mathrm{G}$ : Metastasis promoter $\mathrm{S} 100 \mathrm{~A} 4$ is a potentially valuable molecular target for cancer therapy. Cancer Letters 2009, 280:15-30.

21. Takenaga K, Nakanishi H, Wada K, Suzuki M, Matsuzaki O, Matsuura A, Endo H: Increased expression of S100A4, a metastasis-associated gene, in human colorectal adenocarcinomas. Clin Cancer Res 1997, 3:2309-2316.

22. Rudland PS, Platt-Higgins A, Renshaw C, West CR, Winstanley JH, Robertson L, Barraclough R: Prognostic significance of the metastasisinducing protein S100A4 (p9Ka) in human breast cancer. Cancer Res 2000, 60:1595-1603.

23. Pedersen KB, Nesland JM, Fodstad O, Maelandsmo GM: Expression of S100A4, E-cadherin, alpha- and beta-catenin in breast cancer biopsies. Br J Cancer 2002, 87:1281-1286.

24. Schuyer M, Henzen-Logmans SC, van der Burg ME, Fieret JH, Derksen C, Look MP, Meijer-van Gelder ME, Klijn JG, Foekens JA, Berns EM: Genetic alterations in ovarian borderline tumours and ovarian carcinomas. Eur J Obstet Gynecol Reprod Biol 1999, 82:147-150.

25. Ito Y, Yoshida H, Tomoda C, Uruno T, Miya A, Kobayashi K, Matsuzuka F, Kakudo K, Kuma K, Miyauchi A: S100A4 expression is an early event of papillary carcinoma of the thyroid. Oncology 2004, 67:397-402.

26. Rosty C, Ueki T, Argani P, Jansen M, Yeo CJ, Cameron JL, Hruban RH, Goggins M: Overexpression of S100A4 in pancreatic ductal adenocarcinomas is associated with poor differentiation and DNA hypomethylation. Am J Pathol 2002, 160:45-50.

27. Kimura K, Endo Y, Yonemura Y, Heizmann CW, Schafer BW, Watanabe $Y$, Sasaki T: Clinical significance of S100A4 and E-cadherin-related adhesion molecules in non-small cell lung cancer. Int J Oncol 2000, 16:1125-1131

28. Takenaga K, Nakamura Y, Sakiyama S: Expression of antisense RNA to S100A4 gene encoding an S100-related calcium-binding protein suppresses metastatic potential of high-metastatic Lewis lung carcinoma cells. Oncogene 1997, 14:331-337.

29. Ninomiya I, Ohta T, Fushida S, Endo Y, Hashimoto T, Yagi M, Fujimura T, Nishimura G, Tani T, Shimizu K, et al.: Increased expression of S100A4 and its prognostic significance in esophageal squamous cell carcinoma. Int J Oncol 2001, 18:715-720.

30. Gupta S, Hussain T, MacLennan GT, Fu P, Patel J, Mukhtar H: Differential expression of S100A2 and S100A4 during progression of human prostate adenocarcinoma. J Clin Oncol 2003, 21:106-112.

31. Yonemura Y, Endou Y, Kimura K, Fushida S, Bandou E, Taniguchi K, Kinoshita K, Ninomiya I, Sugiyama K, Heizmann CW, et al:: Inverse expression of S100A4 and E-cadherin is associated with metastatic potential in gastric cancer. Clin Cancer Res 2000, 6:4234-4242.

32. Cho YG, Nam SW, Kim TY, Kim YS, Kim CJ, Park JY, Lee JH, Kim HS, Lee JW Park $\mathrm{CH}$, et al:: Overexpression of $\mathrm{S} 100 \mathrm{~A} 4$ is closely related to the aggressiveness of gastric cancer. Apmis 2003, 111:539-545.
33. Bertram J, Palfner K, Hiddemann W, Kneba M: Elevated expression of S100P, CAPL and MAGE 3 in doxorubicin-resistant cell lines: comparison of mRNA differential display reverse transcriptionpolymerase chain reaction and subtractive suppressive hybridization for the analysis of differential gene expression. Anticancer Drugs 1998, 9:311-317.

34. Kim YJ, Kim MA, Im SA, Kim TM, Kim DW, Yang HK, Heo DS, Lee KU, Choe KJ, Kim NK, et al: Metastasis-associated protein S100A4 and p53 predict relapse in curatively resected stage III and IV (MO) gastric cancer. Cancer Invest 2008, 26:152-158.

35. Arumugam T, Simeone DM, Van Golen K, Logsdon CD: S100P promotes pancreatic cancer growth, survival, and invasion. Clin Cancer Res 2005, 11:5356-5364.

36. Pedersen KB, Andersen K, Fodstad O, Maelandsmo GM: Sensitization of interferon-gamma induced apoptosis in human osteosarcoma cells by extracellular S100A4. BMC Cancer 2004, 4:52.

37. Maelandsmo GM, Hovig E, Skrede M, Engebraaten O, Florenes VA, Myklebost O, Grigorian M, Lukanidin E, Scanlon KJ, Fodstad O: Reversal of the in vivo metastatic phenotype of human tumor cells by an antiCAPL (mts1) ribozyme. Cancer Res 1996, 56:5490-5498.

38. Micale MA, Visscher DW, Gulino SE, Wolman SR: Chromosomal aneuploidy in proliferative breast disease. Hum Pathol 1994, 25:29-35.

39. Pandis N, Heim S, Bardi G, Idvall I, MandahI N, Mitelman F: Whole-arm $\mathrm{t}(1 ; 16)$ and $\mathrm{i}(1 \mathrm{q})$ as sole anomalies identify gain of $1 \mathrm{q}$ as a primary chromosomal abnormality in breast cancer. Genes Chromosomes Cancer 1992, 5:235-238.

40. Forus A, Weghuis DO, Smeets D, Fodstad O, Myklebost O, Geurts van Kessel A: Comparative genomic hybridization analysis of human sarcomas: Il. Identification of novel amplicons at $6 p$ and $17 p$ in osteosarcomas. Genes Chromosomes Cancer 1995, 14:15-21.

41. Nakamura N, Takenaga K: Hypomethylation of the metastasisassociated S100A4 gene correlates with gene activation in human colon adenocarcinoma cell lines. Clin Exp Metastasis 1998, 16:471-479.

42. Li Y, Zhang KL, Sun Y, Yang Y, Chen XY, Kong QY, Wu ML, Liu J, Li H: Frequent S100A4 Expression with Unique Splicing Pattern in Gastric Cancers: A Hypomethylation Event Paralleled with E-cadherin Reduction and Wnt Activation. Trans/ Oncol 2008, 1:165-176.

43. Kohya N, Kitajima Y, Jiao W, Miyazaki K: Effects of E-cadherin transfection on gene expression of a gallbladder carcinoma cell line: repression of MTS1/S100A4 gene expression. Int J Cancer 2003, 104:44-53.

44. Norris MD, De Graaf D, Haber M, Kavallaris M, Madafiglio J, Gilbert J, Kwan E, Stewart BW, Mechetner EB, Gudkov AV, Roninson IB: Involvement of MDR1 P-glycoprotein in multifactorial resistance to methotrexate. Int J Cancer 1996, 65:613-619.

45. Yamada T, Takaoka AS, Naishiro Y, Hayashi R, Maruyama K, Maesawa C, Ochiai A, Hirohashi S: Transactivation of the multidrug resistance 1 gene by T-cell factor 4/beta-catenin complex in early colorectal carcinogenesis. Cancer Res 2000, 60:4761-4766.

46. Berge G, Maelandsmo GM: Evaluation of potential interactions between the metastasis-associated protein S100A4 and the tumor suppressor protein p53. Amino Acids

47. Klingelhofer J, Moller HD, Sumer EU, Berg CH, Poulsen M, Kiryushko D, Soroka V, Ambartsumian N, Grigorian M, Lukanidin EM: Epidermal growth factor receptor ligands as new extracellular targets for the metastasispromoting S100A4 protein. Febs J 2009, 276:5936-5948.

48. Garrett SC, Varney KM, Weber DJ, Bresnick AR: S100A4, a mediator of metastasis. J Biol Chem 2006, 281:677-680.

49. Nakanishi C, Toi M: Nuclear factor-kappaB inhibitors as sensitizers to anticancer drugs. Nat Rev Cancer 2005, 5:297-309.

50. Grigorian M, Andresen S, Tulchinsky E, Kriajevska M, Carlberg C, Kruse C, Cohn M, Ambartsumian N, Christensen A, Selivanova G, Lukanidin E: Tumor suppressor p53 protein is a new target for the metastasisassociated Mts1/S100A4 protein: functional consequences of their interaction. J Biol Chem 2001, 276:22699-22708.

51. Hollstein M, Sidransky D, Vogelstein B, Harris CC: p53 mutations in human cancers. Science 1991, 253:49-53.

52. Kinsella AR, Smith D, Pickard M: Resistance to chemotherapeutic antimetabolites: a function of salvage pathway involvement and cellular response to DNA damage. Br J Cancer 1997, 75:935-945.

53. Weller M: Predicting response to cancer chemotherapy: the role of $\mathrm{p} 53$. Cell Tissue Res 1998, 292:435-445. 
54. Liang H, Zhan HJ, Wang BG, Pan Y, Hao XS: Change in expression of apoptosis genes after hyperthermia, chemotherapy and radiotherapy in human colon cancer transplanted into nude mice. World J Gastroenterol 2007, 13:4365-4371.

Pre-publication history

The pre-publication history for this paper can be accessed here: http://www.biomedcentral.com/1471-2407/10/250/prepub

doi: 10.1186/1471-2407-10-250

Cite this article as: Mencía et al., Overexpression of S100A4 in human cancer cell lines resistant to methotrexate BMC Cancer 2010, 10:250

Submit your next manuscript to BioMed Centra and take full advantage of:

- Convenient online submission

- Thorough peer review

- No space constraints or color figure charges

- Immediate publication on acceptance

- Inclusion in PubMed, CAS, Scopus and Google Scholar

- Research which is freely available for redistribution

Submit your manuscript at www.biomedcentral.com/submit 